\title{
Traces of Scheherazade in Margaret Drabble's The Red Queen: A Transcultural Intertextual Reading
}

\author{
Dr Bushra Juhi Jani \\ Al-Nahrain University, Baghdad. \\ Email: bushrajani@nahrainuniv.edu.iq. https://orcid.org/0000-0002-8981-7003 .
}

\begin{abstract}
This paper examines the transcultural intertextual influence of Scheherazade, the legendary queen and the storyteller of The Thousand and One Nights, on Drabble's The Red Queen (2004), which has a subtitle, "A Transcultural Tragicomedy." It discusses how an appropriation of Scheherazade was utilized by Margaret Drabble in writing, The Red Queen. "But appropriation is what novelists do," Drabble writes in the "Prologue" of her novel, adding, "whatever we write is, knowingly or unknowingly, a borrowing. Nothing comes from nowhere." This paper is a syncretic reading of The Red Queen to show the universality of womanhood and cross-cultural parallels. In this novel, which is based on the memoirs of an eighteenth-century Korean crown princess known as Lady Hong or Lady Hyegyŏng, the protagonist comes from the history of the East, just like Scheherazade, "to retell [her] story." Also like Scheherazade who narrates stories in order to live, the Korean Princess uses storytelling as a strategy for survival. Moreover, the intentions of the novel can be seen in a feminist tradition of historiographic metafictional re-workings of the Orient and the Arabian Nights.
\end{abstract}

Keywords: Margaret Drabble, The Red Queen, The Thousand and One Nights, Scheherazade, intertextuality, transculturality, historiographic metafiction

Margaret Drabble crossed cultural boundaries when she wrote The Red Queen: A Transcultural Tragicomedy (2004). The subtitle, "A Transcultural Tragicomedy," shows that the novel takes interest in intertextual networks. Generally speaking, transcultural intertextuality can be defined as a border-crossing process that engages with various histories and interconnects with different cultural and literary traditions. According to Julia Kristeva (1980), intertextuality is by its nature, invariably transcultural and "indirect"; it is unconsciously borrowed and integral to the historicity and textuality of literature. Transculturality is not limited to the interaction amongst cultures from diverse spatial locations such as the East and the West. It could also refer to time and the continuous interactions between beliefs of the past and the present or of different times (See Bhaduri and Mukherjee, 2016). This paper is a syncretic reading of The Red Queen to show the universality of womanhood and cross-cultural parallels. The intentions of the novel can be seen in a feminist tradition of historiographic metafictional re-workings of the Orient and the Arabian Nights. 
Drabble is engaged in more experimental modes of transcultural writing by deploying stories forms from other cultures. She explains in a prologue and afterword that The Red Queen is based on the memoirs of an eighteenth-century Korean crown princess known as Lady Hong or Lady Hyegyŏng. Beside this direct borrowing, it can be argued that there is also another transcultural intertextual influence of the iconic figure of Scheherazade on Drabble. In Adaptation and Appropriation (2006), Julie Sanders argues that unlike adaptation where we can identify movements of approximation or cross-generic interpretation, an appropriation is "not always clearly signaled or acknowledged" and it may occur in a far less straightforward context (Sanders, 26). In this way, Scheherazade, I would argue, is appropriated in Drabble's text. "But appropriation is what novelists do," Drabble writes in the Prologue of her novel, adding, "whatever we write is, knowingly or unknowingly, a borrowing. Nothing comes from nowhere" (TRQ, 10).' Borrowing from folklore, mythology and fairy tales, as Lisa M. Fiander argues, is key to an understanding of Drabble's work:

This intertextuality reveals much about her feminism, her allegiances to realism, her religious beliefs, and her optimism. It reveals even more about her unwillingness to be pinned down on any of these issues (Fiander, 2006, 210).

Fiander tries to show the elusiveness of Drabble as far as intertextuality is concerned. This article is an attempt to reread The Red Queen in the light of the transcultural intertextuality of Scheherazade, exploring her multilayered roles as a heroine, woman, mother, feminist and narrator.ii

There are many similarities between the Crown Princess and Scheherazade though the first is a historical figure who "was never a queen in [her] lifetime, red or otherwise" (TRQ, 29). Actually Drabble, who was not faithful to the original material of the memoirs, as she mentions in the Prologue, has made her a queen: "I became a queen after my death," the Princess says (TRQ, 29). Another thing is that the Princess, who comes from the history of the East, just like Scheherazade, is here "to retell [her] story" (TRQ, 15). Therefore, being referred to as a queen from the East and a storyteller, the Crown Princess becomes an incarnation of Scheherazade, the legendary female storyteller of the frame story of Alf layla wa Layla or The Thousand and One Nights, which is often known in English as the Arabian Nights. Drabble was possessed by the Crown Princess: "once I had met her, I could not get her out of my mind. She insisted on my attention. She made me follow her, from text to text, from country to country," Drabble writes in the Prologue (TRQ, 9). Drabble also says that she "was originally inspired by [the Princess's] voice and her story," but it could also be said that Drabble was impressed by the figure of Scheherazade, who also has a strong persona and a unique voice (TRQ, 11). In Seven Nights (1984), Jorge Luis Borges states that there is no need to have read this "so vast" book of The Thousand and One Nights to be influenced by it, for "it is part of our memory" (47). However, inspite of the fact that the influence of the Arabian Nights on Western Culture is immense, but it must be acknowledged that what is supposed to constitute Western "memory", is in fact part and parcel of a political, perhaps even colonial or post-colonial, discourse. It can be said that the seeds of an authentic Oriental movement about the East in the entire Europe was planted by the Arabian Nights, as stressed by Al-Olaqi $(2012,393)$. In "The discourse of the Orient," Edward Said states that: 
"The Orient was almost a European invention, and had been since antiquity a place of romance, exotic beings, haunting memories and landscapes, remarkable experiences" (1990, 234).

As stories, they were first translated and published by the French orientalist, Antoine Galland, in 1704 (Sironval, 2006, 220). Then, England was the first country to translate the Nights into English through Richard F. Burton in 1885, who gave it the title The Arabian Nights' Entertainment (Sironval, 2006, 221). According to Said's theory of Orientalism, the tales were not translated but rather "appropriated and domesticated to transmit a certain knowledge about the Orient" (EI Kaidi, 2020). The concern of this paper is more with appropriation rather than post-colonialism.

The influence of the Nights was so all pervasive that, as Robert Irwin suggests, it might be easier to list those writers who were not influenced by the Nights than otherwise (Irwin, 2006, ix). Some of Drabble's contemporary writers, such as, Jorge Luis Borges, John Barth, Italo Calvino and Angela Carter, and her own sister A. S. Byatt, tried to revive Scheherazade and the Nights because they "were interested in the opportunities offered for modernist and postmodernist literary experiments" (Irwin, 2006, $\mathrm{xx}$ ). By describing The Red Queen as "an experiment, and an adventure" which "is unlike anything [she has] ever attempted before," Drabble seems to be doing the same thing as her contemporary writers (Lee, 2007, $496,479)$. She emphasizes the transcultural intertextuality of the novel, which "has to do with trying to cross cultures and seeing that there's a possible contact across cultures," as she states in an interview (Lee, 2007, 496). According to Robert Irwin, writers in modern times have played intertextual games with the original stories of the Nights. "Often overt or covert reference to the Nights has been used as a kind of literary echo chamber in order to give depth to a more modern story" (Irwin, 2006, xiii). The interest of these writers in the Nights, which can be seen as a multicultural emblem, since the origin of the tales themselves come from a multiplicity of sources in medieval times, made them write about it.

Drabble relies on the narrative tools of metafictional parody to challenge the genre conventions of classical writing. As postmodern writer, she adopts a kind of self-conscious fiction that examines the very protest that fiction is created. In Metafiction (2002), Patricia Waugh defines the term as "fictional writing which self-consciously and systematically draws attention to its status as an artifact in order to pose questions about the relationship between fiction and reality" (2). One of these metafictional features is parody. In $A$ Theory of Parody (2000), Linda Hutcheon considers parody as "one of the major forms of modern self-reflexivity; It is a form of inter-art discourse" (2). Metafiction uses the postmodern technique of parody by incorporating the past into the present. This technique is evident in The Red Queen in which two different levels of past and present are depicted and set apart.

The Red Queen is divided into two distinct sections: "Ancient Times" and "Modern Times," with the latter section ending in "Postmodern Times" - fitting for "a postmodernist, metafictional novel" (Stovel, 2007, para. 2). "Ancient Times" is primarily about the memoirs of the Crown Princess, narrated by her ghost. It is about her marriage at the age of ten to the heir to the throne, Prince Sado; her survival of court intrigues; her loss of her firstborn child and her husband's descent into insanity and subsequent murder by his own father, King Yŏngjo, who sends him to an eight-day death confined in a rice chest. "Modern Times" is about the afterlife of these memoirs, two hundred years later in modern England. In this section, Barbara Halliwell or Babs, an academic, reads the book on a flight heading from Heathrow to Korea, where she is to take part in a conference to be held in Seoul. She finds herself totally haunted by the Crown Princess's 
story. The first part is not only postmodern, or metafictional, but also fictionalizes history. Drabble turned historical facts into what Linda Hutcheon calls in her Politics of Postmodernism (1989), "historiography," which is "an attempt to comprehend and master [the past] by means of some working (narrative/ explanatory) model that, in fact, is precisely what grants a particular meaning to the past" (Hutcheon, 64). This "fictionalized historical representation" of the past involves "historiographic metafiction," as Hutcheon asserts (58), although Drabble states that "this is not an historical novel" because it is not entirely based on facts, but also on Drabble's speculation (TRQ, 11). Beside this intersection of facts and fiction, there are other forms of historiographic metafiction in the novel, such as paratextuality. According to Hutcheon, metafictional paratextuality can be found in the form of "chapter headings and epigraphs" as well as in "footnotes, forewords, and epilogues" and other devices (Hutcheon, 1989, 84). Drabble uses many of these devices. For example, in the Prologue, Drabble refers to the historical material she used to write the novel. She even includes a bibliography.

The second part of the The Red Queen is entirely fictitious where we are introduced to Babs and learn about the affinities between her and the Crown Princess. Like the Princess, Babs loses her first child, and her husband, Peter, goes mad because of his difficult relationship with his father. Though Peter has not murdered anyone, he has tried to strangle his wife during a quarrel. In this part, Babs has a short love affair with a dying man, Jan van Jost, a world-renowned Dutch sociologist. In "Postmodern Times," Drabble writes herself into a final scene, "extend[ing] the metafictionality" of the novel and recreating the role of Scheherazade in the Arabian Nights (Stovel, 2007, para. 10). The novel ends with Babs and Van Jost's widow raising a daughter, an adopted Chinese orphan, and Drabble, herself, as a character in the story, accepting a commission to write about the memoirs.

In The Red Queen, Drabble, like Scheherazade, attempts to link reality with magic by incorporating fantastic elements into a more realistic narrative. This nod at magical realism in the novel lies in the pervasive ghost voice of The Red Queen. Though fantastic, the ghost voice is "firmly anchored in realism" (Franková, 2011, 85). It links The Red Queen to contemporary reality. Drabble has used a "Gothic setting" in order to "challenge the assumptions of realism" (Fiander, 2006 , 13). For example, the ghost lives in modern times, reading books and newspapers and surfing the Internet. The ghost uses these sources, just as historiographers and novelists do, to refurbish the story of her life and to draw comparisons and clarify in retrospect. She compares herself with other princesses and queens and she even competes with them: she says of Marie Antoinette, "we compete beyond the grave" (TRQ, 90). Although Drabble has associated herself in essays and interviews with the tradition of realism, she actually produces what Christopher Bigsby describes as "by no means an innocent realism" (qtd in Fiander, 2006, 14). This is manifested in what Lisa Fiander calls "the introduction of elements that normally would have no place in realistic fiction" (Fiander, 2006, 14). The Princess has written the story of her life when she was alive, but now her ghost is the one who is "to tell and retell [her] tale, as [she] told and retold it upon earth" (TRQ, 52). It seems that Drabble has become the ghost-writer of the memoirs. By assuming the task of creating a new story through the retelling of the old, Drabble resembles Scheherazade. According to John Barth, "the contemporary writer resembles Scheherazade, whose life depends on her ability to entertain the king with old stories made new" (Jablon, 1997, 30). In "Narrate or Die" (1999), A. S. Byatt states, "we are all, like Scheherazade, under sentence of death, 
and we all think of our lives as narratives, with beginnings, middles and ends," but these endings of narratives involve "endless new beginnings" like the Arabian Nights, in which "the narrative plot is potentially capable of proliferating the tales infinitely" (Byatt, 1999; Cavarero, 2000, 124).

Although Drabble does not model The Red Queen on Scheherazade, as she said, yet the novel is close to Scheherazade's story in many aspects. One is the theme of womanhood. The subject of women and their lives is a topic that Drabble continually engages with and explores in almost all her novels. In her effective commentary on women and writing, "The Laugh of the Medusa," Hélène Cixous argues that women must "write women," that is, must write of their own experience as women (Cixous, 1976, 875). When writing The Red Queen, "Drabble indeed 'writes women'": by choosing two female characters, a Scheherazade-like figure and a fictional contemporary woman, producing new meanings for these female characters and for her readers (Rubenstein, 1989, 95). Therefore, The Red Queen "bears similarities with all of Drabble's fiction, in the sense of relating women's lives against the social backdrop of the times" (Franková, 2011, 80). In fact, "Drabble's lifelong obsession with women's roles held her captive to Lady Hong's powerful, horrid story" (Lee, 2007, 478). In The Red Queen, the Crown Princess and Babs resemble Scheherazade and her younger sister, Dunyazade. The Princess says "I need [Babs'] services" to survive, which is similar to Scheherazade, who needs Dunyazade's help to start recounting stories every evening for one thousand and one nights to save herself and the other women in the kingdom (TRQ, 128) (Burton, 1885, 12). In The Red Queen, the Princess says that she has selected Babs as an "envoy, who will prolong my afterlife and collaborate with me in my undying search for the meaning of my sufferings and my survival" (TRQ, 15).

The Princess also chooses a woman as an envoy, the parallels between her and her envoy being remarkable: "both women have suffered grievous loss" (Lee, 2007, 478). The novel also sheds light on differences in the status of women in the past and the present. Like Scheherazade, the Princess is "an intelligent and an articulate woman, by any relativist and multicultural standards that you may choose to invoke" (TRQ, 14). However, also like Scheherazade, she has little freedom of movement of her own and very little self-determination. Drabble refers to the constraints that governed women's lives in this period, not only in Korea but in most countries in the world. However, the Princess lived a long and "privileged" but very circumscribed and regulated life (TRQ, 33). Babs, on the other hand, the modern intelligent woman, "has freedom to act, freedom to move, freedom to choose. She earns her own living" (Lee, 2007, 494-95). In spite of these changes in the status of modern women, the Princess and Babs have the same experiences that Scheherazade has also been through. They share the same experience of being wives and mothers. As far as women's experiences are concerned, Drabble wants to show that these experiences endlessly repeat, regardless of women's status or class or time or place or culture. According to Drabble, the Princess's story is "a universal story," celebrating the universality of women's experiences (Lee, 2007, 492).

The universal experience of motherhood is highly emphasized in The Red Queen. Motherhood is also important to Scheherazade and plays a part in her survival. Drabble, who is a mother herself, presents the topic of motherhood in most of her novels as "a prominent aspect of the female protagonist's character" (Rayson, 1978, 43). Motherhood is presented in these novels not as an institution under male control, as it is so often defined, but, as Ann Rayson indicates, "as 
the relationship of a woman to her powers of reproduction and to her children" (Rayson, 1978, 43). Rayson also states that "having a child, in Drabble's novels, is not an end in itself, but one effective way available to a woman - and not to a man - of growing and coping with change, of learning to live" (Rayson, 1978, 43). For Drabble, motherhood empowers women, which is exactly what motherhood did to Scheherazade.

In the epilogue or "Conclusion" of the Arabian Nights, we discover that Scheherazade has given birth to three sons (Burton, 1885, 246). Therefore, it is not for any reason than for the sake of their children that Scheherazade, the mother, begs Shahryar, for the first time, to spare her life, which he does. Shahryar acknowledges that her role as mother is one of the qualities that saved her. He admits to her father, saying, "indeed I have found her pure and pious, chaste and ingenuous, and Allah hath vouchsafed me by her three boy children, wherefore praised be He for his passing favor" (Burton, 1885, 247). Motherhood gives Scheherazade some sort of power that obliges Shahryar to concede to her will. In "Shahrazâd Is One of Us," Susanne Enderwitz states that "it is to her and our relief that she is able to reassure herself with her three sons, just in case the king still bears traces of his former character" (Enderwitz, 2004, 196). We are told that Scheherazade's three children are "one walking, one crawling, and one suckling" (Burton, 1885, 246). The ages of these children show the difficulties and challenges she has to overcome as a mother and as a wife of a bloodthirsty misogynist. Scheherazade is almost continuously pregnant: we can estimate that "her sons would have been born on night 270, night 600 and night 930, thus making them 731 days old (2 years), 401 days old (13 months) and 71 days old" (DeVille, 2006, 20). Enduring all that makes Scheherazade a brave mother.

The Princess finds in motherhood pleasure and power, as Scheherazade does. As a mother, the Princess thinks that her survival is important for the sake of her progeny:

My life was needed. My son and my grandson needed me. I could not abandon them. I survived for them. (I could even argue that my kingdom needed me, but that would be a grandiose claim, a masculine and dynastic claim, and I do not make it.) (TRQ, 15).

Although she feels that "it was indeed [her] duty to survive," some accuse her of being governed "by a selfish will to survive" and that her love of her sons was "politic" and for "personal ambition and family pride" (TRQ, 42). She defends herself against these accusations by showing that her maternal love is "a consuming passion" (TRQ, 53). She defines motherhood as "a primitive maternal obsession, a fierce white cataract to which I gave the name of love. And yet it was love" (TRQ, 52-53). She considers maternal love as "inborn" just like that of her mother cat, which "was the most tender and gentle of mothers" (TRQ, 42):

I was that mother cat. When my first son was born, in 1750, such a passion of adoration and love broke in my breast, like the breaking of the waters of my womb. I was suffused with warmth. I reached out my arms to him and wept with joy. (TRQ, 42)

The Crown Princess goes on, describing her maternal love for her little first-born, Ǔiso, her second son, Chŏngjo, and her two daughters. The Princess's experience differs from that of Scheherazade in that she loses her first-born child, Ǔiso, who suffered from incurable weaknesses. Again, the 
Princess is accused of being "cold and unfeeling," for the loss of Ǔiso, "the heir to the heir" (TRQ, 47; 43). She describes her feelings after the loss, saying:

But in truth I was in despair. Believe me, I mourned my little son, and not my place at court, or my status as mother of the Grand Heir. He was my baby, and the first great love of my life. My nature grieved, and not my dignity. (TRQ, 47)

But if Scheherazade, or any woman, loses a child, that would make her feel no less than the Princess, who believes that "the loss of a child is like no other loss and can drive one to irrationality, to wildness and despair" (TRQ, 47). The Princess's feelings of loss are shared by Babs, who mourns for the sad death of her only child, Baby Benedict. Babs does not think she will ever attempt to have another baby because "it is too high a risk. She has a chromosome hazard" (TRQ, 214). Drabble raises questions about a childless woman, "does she feel deprived, maternally deprived?," Babs "does not think that a woman has a right to a baby" for she "has a full life without a baby" (TRQ, 214). At the end of the novel, she becomes the second mother to a Chinese adopted girl, Chen Jianyi. It seems that this adoption heals Babs emotional wound of being childless. It helps her "come through it with a sense of living for the future rather than the past," as Drabble says in her interview with Young-Oak Lee (495). She adds that this Chinese girl "is a representation of [Babs'] survival and her adjustment," unconsciously emphasizing the Scheherazadian theme of survival and motherhood (Lee, 2007, 495).

The Red Queen also presents "unnatural" kinds of mothers, such as Lady Sŏnhŭi, who effectively adds her signature to the death sentence of her son, Prince Sado, because she wishes "to preserve the life of the king, and the life of the Grand Heir, and the bloodline of the 400-yearold dynasty" (TRQ, 102). However, she protests her love for her son, whom she says "she loved ten thousand times more than she loved any other" (TRQ, 102). For Drabble, this historical figure, who does not fit with her norms of what a mothers constitutes, remains rather a mysterious figure:

And I couldn't really understand her. I couldn't really understand her motivation. She sacrificed her son. That I found terrifying, really terrifying. Maybe I found that unacceptable. Maybe I found that-I couldn't describe it. It was too upsetting for me. The material is very disturbing. Very disturbing (Lee, 2007, 490).

Although the existence of such unnatural mothers is unacceptable by Drabble, Scheherazade seems to be familiar with them, as she talks about them in one of her tales. In the story of princes Amgiad and Assad, the "unnatural queens," as Shaherazade calls them, Queen Badoura and Queen Haiatalnefous, fall in love with each other's sons, Amgiad and Assad, but the brothers repulse their stepmothers' advances (Limbird, 2011, 266). The Queens accuse the two young men of trying to seduce them and make their husband King Camaralzaman send his sons away to be executed (Limbird, 2011, 266). However, the princes are later reunited with their father, who has learned of their innocence (Limbird, 2011, 266; Stoker, 1994, 285-86).

Scheherazade's tale about this Oedipal-like passion of these two mother queens calls to mind Doris Lessing's story, Grandmothers, in which two friends, Roz and Lil, are lovers to each other's sons (Lessing; Jaggi). It is possible that Lessing had based her story on Scheherazade's. If so, it is then another influence of the Nights on Drabble's contemporary writer and friend (drabble, 2013). 
Another aspect of motherhood that brings the Crown Princess close to Scheherazade is that both women act as mother-figures to their own sick husbands. In The Arabian Nights, Scheherazade has many roles. In addition to being Shahryar's wife and the bearer of his children, Scheherazade mothers Shahryar himself during the course of one thousand and one nights, telling him stories every night. Jennifer DeVille suggests that the act of telling stories every sunset "calls to mind the image of a parent reading fairy tales to his or her child at bedtime" (DeVille, 2006, 19). For the Crown Princess mothering Sado takes the form of sympathy and understanding: "Evidence for my sympathy and understanding is there, in those memoirs, for anyone who troubles to read them in the right spirit" (TRQ, 69). She thinks that Sado "relied on my support and my understanding" (TRQ, 76). She does not even resent him having a mistress. She finds herself "obliged to set myself up as his warden and his protector, as well as his wife" (TRQ, 84). Although he injures her once "during one of these domestic rows" when "he threw a chessboard at [her], which hit [her] left eye and caused a hideous swelling," she justifies this by saying that her "husband Prince Sado had been mad, and was therefore not responsible for his acts" (TRQ, 82; 125). She pities him: "It is hard to describe the pity I felt for this violent and unhappy man" (TRQ 91). She compares the loss of Sado to that of the loss of her first-born child and her second son, King Chŏngjo, who died, "suddenly and without warning," "after twenty-four years on the throne" (TRQ, 130). She cannot say which loss was the worse for her, but "at least my sons died of natural causes. That is a comfort," the Princess says (TRQ, 115).

Unlike Shahryar's gendered madness, which is caused by an unfaithful wife, Sado's madness is the result of an intense relationship with his father, King Yongjo. The Crown Princess has "psychological insight into the dilemma of her husband," as Drabble points out (Lee, 2007, 483). She can see "so clearly without blaming, without distortion," therefore she holds the king responsible for Sado's derangement because of his "excessive demands and excessive expectations" (TRQ, 24; Lee, 2007, 483). Nothing Sado does ever pleases this "remorseless [and] relentless" father, whom the Princess describes as "capricious, vindictive, unfatherly" (TRQ, 52). She asks, "How could Sado not run mad? He was spurned and rejected and tormented. How could he honour such a cruel father? He was caught in a trap from which there was no escape" (TRQ, 52). Sado develops a clothing phobia at first. He frequently slashes his clothes because he cannot decide what to wear. His condition deteriorates and he becomes murderous, incestuous and suicidal.iii He has an affair with one of his sisters. He kills many eunuchs and courtesans. He even kills his mistress, Lady Pingae. He tries to kill himself but fails. The Princess, who does not stay in the historic past, but comes up-to-date as a ghost that has been reading modern literature and Freudian theories, labels the afflictions of her husband with psychological concepts, unknown in her time: "My husband would now, in your age, be likely to be classified as a paranoid schizophrenic" (TRQ, 72). She also tries to describe the son-father relations using Freudian concepts, such as that of "Oedipus" (TRQ, 253):

Perhaps from Sado's birth onwards the king saw my husband as a rival, as a potential parricide. [...] All fathers find a rival in a son. Maybe that is why we talk so much of filial piety, in an effort to restrain our natural impulses towards parent-murder (TRQ, 25).

Drabble comments on this, saying, "there were one or two moments between the father and the son that are like King Lear, Oedipus Rex-extraordinary moments of confrontation" (Lee 483). The same thing applies to Babs' husband, Peter, who suffers from "a psychological illness" which 
makes him like Sado, violent, though mostly towards himself, and suicidal (TRQ, 151). Like Sado, Peter's illness is caused by his father, who had demanded too much of his son: "His son had failed, and had gone mad. The father had not been a king, but he had been as cruel and as despotic as a king. His son, like Prince Sado, had never been allowed to succeed" (TRQ, 151). Being afflicted by psychological illness caused by filial relationships, Sado and Peter become close to Shahryar's case, psychologically speaking. Shahryar, whose madness is caused by "sexual jealousy" after the betrayal of his first wife, loses all his trust and love for women (Cheira, 2012, 58). He kills his wife and begins his campaign of revenge on all women by wedding a virgin each day, bedding her that night, and then murdering her at dawn. According to Robert L. Mack, Scheherazade seems to have recognized that the king is possessed by a madness that is curable, and similarly comprehends that her narrative is "the psychological techniques that will work therapeutically to effect a cure for his pathological misogyny" (Mack, 2008, 73). By choosing the bed as a place to cure him, Scheherazade, who is considered "the first female psychotherapist in history," creates the first Freudian "analyst's couch" in reverse, because she is the one who is talking while her patient is listening (Cheira, 2012, 58; Warner, 2011, 419). Unlike Shahryar, whose madness is curable, Sado's and Peter's are "helpless" (TRQ, 168). Sado was "irrevocably mad, past hope, past cure" and "he cannot be blamed" as the Princess observes, "but he cannot be saved" (TRQ, 103). Though he does not have the same fate as Sado, Peter ended up at a Retreat (TRQ, 168). Unlike Scheherazade, both the Princess and Babs could not help their husband. The Princess feels that she "failed my husband Prince Sado. I could not help him" (TRQ, 38). Babs, who also "had not been able to help" her husband, visited him at his retreat once a week "to calm her conscience" (TRQ, 156; 246).

Drabble has described The Red Queen as a feminist book. Yet, she is rather "ambivalent" about using the term feminist to describe herself because she claims that her only thought was to "reflect the female experience" (Johnson, 2011). iv Drabble's view of reflecting the female experience does marry to a syncretic view of transculturalism. In The Red Queen, Drabble is experimenting modes of transcultural writing by deploying female experiences from other cultures. In the novel, the Princess says that "I am a prime and occasionally quoted example of the new 'her-story'," rather than "his-tory" (TRQ, 14). The novel illustrates women's depression and stress in a male-dominated society (Gupta and Singh, 2014, 24). However, if we read The Red Queen as being based on Scheherazade, then it depicts a modern feminist view of her. Drabble must be aware of contemporary authors, who, consciously or unconsciously, have displayed a renewed interest in Scheherazade as "a modern-day feminist" (Malti-Douglas, 1997, 40). ${ }^{\vee}$ Many women writers from the mid-twentieth century onwards have attempted to redress the injustice of Shahryar's treatment of women and his threat to execute Scheherazade (Irwin, 2010, 254). One of these is the American feminist Ethel Johnston Phelps, whose short story, "Scheherazade Retold," is a retelling of the frame story of the Nights, but giving it a new feminist ending (Phelps, 1981). Phelps, as Fedwa Malti-Douglas argues, "has Shahrazad continue telling stories until the king's early demise, upon which she herself handles the revision and publication of the text" (MaltiDouglas, 1991, 26). In the epilogue of the actual Nights, the king gives the order to have Scheherazade's tales written down. This ending, according to Malti-Douglas, gives rise of "male preeminence" because it is Shahryar who copied the stories and his male successors distributed them, so Phelps tries to reverse this (Malti-Douglas, 1991, 28). In The Red Queen, Drabble can be 
seen as doing what Phelps has done. The Princess outlives her husband and her father-in-law and she writes her own story: "I wrote various accounts of my story during my earthly lifetime, and I must say that they were well written" (TRQ, 14).

Although Scheherazade delivers only the oral part of her stories, the Nights defends her and holds her as heroic woman, mother and narrator. The Thousand and One Nights is known to be "The Book without Authors," being anonymously written by "presumably male authors" (Irwin, 2004, 42; Haase, 2008, 857). However, Muhsen Mahdi argues that "to ignore the name and identity of a book's author or authors does not mean that it is 'a book without an author,' as some scholars are in the habit of describing the Nights" (Mahdi, 1995, 142). Ibrahim Muhawi holds the assumption that "the 'authors' of the Nights were women rather than men" because of 'the role that cultivated urban ladies played in the Nights' and "the fact that, in the Arab world, oral folktales are narrated primarily by women" (Muhawi, 2005, 329, 335). Contrary to Muhawi's assumption, Adriana Cavarero believes that Scheherazade is not the author of the stories, but rather the one who transmits them orally because "the young Arab girl reads, remembers and recounts" (Cavarero, 2000, 123). However, Cavarero suggests that "the art of choosing the occasions and the modes of the narration is nonetheless completely hers" $(2000,123)$. As for Foucault, he sentences Scheherazade to death when he proclaims the "death of the author" in his essay, "What is an Author?," in which he examines the "relationship between writing and death" and how death is "manifested in the effacement of the writing subject's individual characteristics" (Foucault, 1998, 206). He gives the example of The Arabian Nights, in which "the motivation, as well as the theme and the pretext" of the narrative was "the eluding of death" (Foucault, 1998, 206):

One spoke, telling stories into the early morning, in order to forestall death, to postpone the day of reckoning that would silence the narrator. Scheherazade's narrative is an effort, renewed each night, to keep death outside the circle of life (Foucault, 1998, 206).

Foucault does not directly say that Scheherazade is the real author of the One Thousand and One Nights, but rather indirectly, as some critics, such as Muhawi, have indicated, he implies that she is the author:

In this discourse Foucault makes two significant assumption (sic): that the Nights belongs to the same European culture that produced the Greek epic, and [...] that Shahrazad is the "author" of the Nights (Muhawi, 2005, 334-35).

Since Foucault examines "the author's disappearance," Muhawi believes that the Nights "consists of a set of expanding strategies for making the 'author' disappear" (Foucault, 1998, 206; Muhawi, 2005, 335). Thus, according to Muhawi's interpretation, we can establish that the Nights is textually "postmodern," or metafictional, and its author is Scheherazade:

Once the frame tale is established, Shahrazad disappears in the cycles of tales she narrates, while within these cycles, the narrator of the frame story disappears in the embedded tales (Muhawi, 2005, 335).

If we assume that Scheherazade is the real author, then she, like Drabble in The Red Queen, manages to create a metafictional text and to "put herself into the text," to use Cixous terms (Cixous, 1976, 875). The Princess also puts herself into the text in both oral and written form. The written form of the memoirs are sent by mail to Babs to read and publicize, while the ghost of the 
Princess is given Scheherazade's oral voice, wandering in contemporary times, breaking "the silence of death" to narrate her story (TRQ, 136). The Princess has been given "a new voice in our time," as Drabble writes in the Prologue (TRQ, 10). This voice, like that of Scheherazade, has been mixed with the voice of the author and, as Drabble indicates, "inevitably, with the voices of her various translators and commentators, all of whom will have brought their own interpretations to her and imposed their personalities upon her" (TRQ, 11). The ghost narrates the story of how the Princess managed to survive and continues to survive: "I have been dead now for 200 years, but I have not been idle. I have been rethinking my story, and my history" (TRQ, 14). The Princess says that "I am here to tell and retell your tale, as I told and retold it upon earth" (TRQ, 52). Both the Princess and Scheherazade use storytelling as a strategy for survival (Pinault, 1992, 84). The Crown Princess does not want her long and extraordinary existence to be forgotten, so she sends her ghost to Babs. In Babs we find a new Scheherazade: "She is older, wiser and, on the whole, happier now" (TRQ, 168). Her husband "ended up in such profound, imprisoned, helpless inertia, imprisoned in a well-guarded and expensive Retreat" (TRQ, 168). This destiny would have been arranged for Prince Sado or King Shahryar had they lived in modern times.

Storytelling and the prolonging of life are prominent themes in the Nights; as Faten Morsy says, "storytelling has proven to be the conqueror of the ultimate and all-silencing event, death" $(2007,231)$. As in the Nights, the themes of life, death and survival are dominant in The Red Queen. The Princess survives, breaking the chains that confined her during her lifetime and defeating death after her death. Drabble says in the Prologue, "after death, [the Princess] is no longer confined by the culture that imprisoned her. She speaks out from it. She represents a peculiar version of the phenomenon of life after death" (TRQ, 11). The Princess manages to survive and continues to survive by telling stories. The Crown Princess does not want her long and extraordinary existence to be forgotten, so she sends her ghost to Babs. As Scheherazade did "over nearly ten centuries," the Princess finds in storytelling the means to survive violence, death and extinction (Fedwa, 1997, 7).

Like Scheherazade, both the Princess and Babs speak about the difficulties women face during the period when they are or were living. Like Scheherazade, the Crown Princess extends herself beyond the boundaries of the body to narrate her story and to give voice to the voiceless women who "lived in repressive times" (TRQ, 37). Her self-extension is through the ghost voice. Like Scheherazade and her life-saving stories, the implied author wants to use her artistic talents to live like the Crown Princess beyond time. Drabble says in the Prologue: "some books outlive their authors. I do not think that I am speaking here of narrative skill, or of literary talent, although the Crown Princess had both" (TRQ, 11). Drabble, too, probably wants to have a life after death and to survive through her work, like Scheherazade. However, the American critics W.K. Wimsatt and Monroe C. Beardsley (1946) would argue that there is an intentional fallacy that is involved in this approach. If judgment is to be aesthetic, the meanings that we atribute to the work must concern itself with that we see in it, whatever the artist intended. What we see is Drabble's use of this quotation, "the dead weep with joy when their books are reprinted," from Alexander Sokurov's film "The Russian Ark" (2003), as an epigraph and introduction to The Red Queen (TRQ, 8). The ghost of the Crown Princess feels "proud" because her "writings survived" $(T R Q, 132)$. She has "watched the process of their dissemination with interest and amazement. My 
story has seized the imaginations of generations then unborn" (RQ 133). We are reminded of Foucault's ideas in "What is an Author?" because The Red Queen is dead, but her text survives.

When Drabble says of the Korean Princess that she "did actually belong to the future" we can see that this is also true of Scheherazade (Lee, 2007, 484). Both the Princess and Babs can be seen as representations of Scheherazade or modern-day Scheherazade. Susanne Enderwitz says that Scheherazade's wit and self-assurance place her ahead of all other women, in particular of the women of later or more "advanced" ages (Enderwitz, 2004, 191). Likewise, the Crown Princess is "a prescient woman who lived out of time," as described by Drabble in the Prologue (TRQ, 11). Babs thinks that the Princess "must have been hundreds of years ahead of her time. Indeed, time has not yet caught up with the Crown Princess" (TRQ, 149). In contrast, Babs is described as a "vain, ambitious and flirtatious academic, who is at an age when she still seems to think she has so many free choices to make" (TRQ, 245). With their intelligence and knowledge, The Red Queen and Scheherazade incarnate modern day woman.

In the analysis of The Red Queen, the fact that Scheherazade is a figure for metafictional narrative seem to intersect. The Red Queen shows how storytelling helps the Crown Princess to be remembered and to survive in the present time. Her story and its personal details mirror and interconnect with Babs' story. It helps Babs overcome her insecurities and develop a new sense of herself. The Crown princess, like Scheherazade, survives as long as her story is remembered.

\section{Notes}

\footnotetext{
' Margaret Drabble, The Red Queen (New York: Penguin Group, 2004). All subsequent references to the novel will be in the main body of the text as an abbreviation of the novel (TRQ) followed by a page number.

ii Her name is translated as Shahrazad, Shahrzad, Sheherezade, Shéhérezade or Scheherazade. I will settle on the latter spelling, which Sir Richard Burton used in his book the Arabian Nights. The same thing applies to other names, such as Shahryar and Dunyazade.

iii See "The Search for Identity ..." by Bushra Juhi Jani, which is about how "childhood experiences or troubled families" can create murderers and terrorists (p. 2).

iv According to Ellen Cronan Rose, Drabble "is a feminist novelist - most emphatically if paradoxically in those of her novels which are not, on the face of it, 'women's books'" $(1988,86)$.

v Drabble's sister A. S. Byatt decribes Scheherazade as "the strongest and cleverest heroines in world literature" (1999). Byatt wrote the feminist novella, "The Djinn in the Nightingale's Eye" (1994), the title piece of a collection of five stories, in which the two main characters, the Middle-aged British narratologist Gillian Perholt and the djinn, can be identified with the figure of Scheherazade.
}

\section{References}

Al-Olaqi, Fahd Mohammed Taleb Saeed (2012). The Influence of the Arabian Nights on English Literature: A Selective Study. European Journal of Social Sciences, 31.3: 384-396

Arana, Marie (2009). Margaret Drabble: Resolutely Herself. Washington Post, 20 September. 
Bhaduri, Saugata \& Mukherjee, Indrani. (Eds). (2016). Transcultural Negotiations of Gender Studies in (Be)longing. New Delhi: Springer India.

Borges, Jorge Luis (1984). Seven Nights. Trans. by Eliot Weinberger. New York: New Directions Books.

Burton, Sir Richard (1885). A Plain and Literal Translation of The Arabian Nights Entertainments. Now Entitled The Book of the Thousand Nights and a Night, Vol. 1. USA: Burton Club.

Byatt, A.S. (1999). Narrate or Die: Why Scheherazade keeps on talking. New York Times Magazine, 18 April.

Cavarero, Adriana (2000). Relating Narratives: Storytelling and Selfhood. Trans. with an introduction by Paul A. Kottman. New York: Routledge.

Cheira, Alexandra. (2012). Madness and psychotherapy through the looking glass: the case of King Shahryar's ma(d)gic internal wound and fair(y) Scheherazade. In Fátima Alves, Katrina Jaworski \& Stephen Butler (Eds.), Madness in Plural Contexts: Crossing Borders, Linking Knowledge (pp. 57-66). Oxford: Inter-Disciplinary Press.

Cixous, Hélène (1976). The Laugh of the Medusa. Signs, 1.4 (Summer): 875-893.

DeVille, Jennifer Suzanne. (2006). Scheherazade Reborn in the Contemporary Francophone Fiction of Leïla Sebbar, Pierre Karch and Vinciane Moeschler. Unpubl. Diss., The University of North Carolina.

Drabble, Margaret. (2013). My Hero: Doris Lessing. The Guardian, 23 November.

---. (2004). The Red Queen. New York: Penguin Group.

El Kaidi, Youssef. (2020). 'One Thousand and One Nights': When East Meets West. Inside Arabia, Dec. 5, 2020.

Enderwitz, Susanne (2004). Shahrazâd Is One of Us: Practical Narrative, Theoretical Discussion, and Feminist Discourse. Marvels \& Tales, 18.2: 187-200.

Fiander, Lisa M. (2006). Margaret Drabble. In David Scott Kastan (Ed.), The Oxford Encyclopedia of British Literature (209-211). Oxford University Press.

Foucault, Michel. (1998). What is an Author?. In James D. Faubian (Ed.), Aesthetics Method, and Epistemology (pp. 205-22.). New York: The New Press.

Franková, Milada. (2011). The Red Queen: Margaret Drabble's (Auto )Biographical Pastiche. Brno Studies in English. 37. 2: 79-86

Jablon, Madelyn. (1997). Black Metafiction: Self-Consciousness in African American Literature. Iowa: University of Iowa Press.

Johnson, Andrew. (2011). Margaret Drabble: The original angry young woman. Independent, Saturday 22 October.

Jones, Steven Swan. (2002). The Fairy Tale: The Magic Memory of Imagination. New York: Routledge.

Gupta, Usha Rani \& Singh, Sharanpal. (2014). A Psychological Study of Margaret Drabble's The Red Queen (2004). International Journal of Literature and Arts, 2.1: 24-30

Haase, Donald. (Ed.). (2008). The Greenwood Encyclopedia of Folktales and Fairy Tales: Q-Z. Westport, CT: Greenwood Publishing Group.

Hutcheon, Linda (1989). The Politics of Postmodernism. London: Routledge.

---. (2000). A Theory of Parody: The Teachings of Twentieth-century Art Forms. University of Illinois Press. 
Irwin, Robert. (2006). Preface. The Arabian Nights and Orientalism: Perspectives From East \& West. Yuriko Yamanaka and Tetsuo Nishio (Eds.). London: IB Tauris. vii-xiii.

---. (2004). The Arabian Nights: A Companion. London: Tauris Parke Paperbacks.

---. (Ed.). (2010). The Arabian Nights: Tales of 1,001 Nights, Vol. 3. Trans., Malcolm Cameron Lyons. New York: Penguin classics.

Jaggi, Maya. (2003). Old Lives, Young Loves: Doris Lessing's Latest Collection of Stories. Guardian, 22 November.

Jani, Bushra Juhi. 2020. "The Search for Identity in Doris Lessing's The Good Terrorist and Abdallah Thabit's The Twentieth Terrorist." Rupkatha Journal on Interdisciplinary Studies in Humanities, 12.5: 1-11. http://rupkatha.com/V12/n5/rioc1s6n1.pdf.

Kristeva, J. (1980). Desire in Language: A Semiotic Approach to literature and Art. Gora, T., J. Alice and L. S. Roudiez (trans.) in L. S. Roudrez (ed.), Columbia University Press, New York.

Lee, Young-Oak. (2007). An Interview with Margaret Drabble. Contemporary Literature. 48.4 (Winter): iv-498

Lessing, Doris. (2004). Grandmothers. London: Harper Perennial.

Limbird, J. (2011). The Arabian Nights' Entertainments: Consisting of One Thousand and One Stories. London: Ghent University.

Lowry, Elizabeth. (2012). Visions of the Arabian Nights. The Times Literary Supplement (TLS), 18 January.

Mack, Robert L. (2008). Cultivating the Garden: Antoine Galland's Arabian Nights in the Traditions of English Literature. Saree Makdisi \& Felicity Nussbaum (Eds.), The Arabian Nights in Historical Context: Between East and West (pp. 51-81). New York: Oxford University Press.

Mahdi, Muhsen. (1995). The Thousand and One Nights. Brill: Leiden and New York.

Malti-Douglas, Fedwa. (1991). Woman's Body, Woman's Word: Gender and Discourse in Arabo-Islamic Writing. Princeton University Press.

---. (1997). Shahrazad Feminist. Richard G. Hovannisian and Georges Sabagh (Eds.), The Thousand and One Nights in Arabic Literature and Society, (pp. 40-55). Cambridge: Cambridge UP.

Martin, Rachel. (2013). Scheherazade: From Storytelling "Slave" to "First Feminist." Boston's NPR news Station. 9 June.

Morsy, Faten I. (2007). Thus Spoke Shahrazad: Contemporary Arab Women's Recent Rewritings of The Nights. Genre, An International Journal of Literature and the Arts on Women. 28: 231-248.

Muhawi, Ibrahim. (2005). The "Arabian Nights" and the Question of Authorship. Journal of Arabic Literature. 36.3: 323-337.

Rayson, Ann. (1978). Motherhood in the Novels of Margaret Drabble. Frontiers: A Journal of Women Studies. 3.2 (Summer): 43-46.

Rose, Ellen Cronan. (1988). The Sexual Politics of Narration: Margaret Drabble's Feminist Fiction. Studies in the Novel, 20(1): 86-99. Retrieved July 28, 2021, from http://www.jstor.org/stable/29532546

Rubenstein, Roberta. (1989). Sexuality and Intertextuality: Margaret Drabble's "The Radiant Way." Contemporary Literature. 30.1 (Spring): 95-112.

Phelps, Ethel Johnston. (1981). The Maid of the North: Feminist Folk Tales From Around The World. New York: Holt, Rinehart and Winston. 
Pinault, David. (1992). Story-Telling Techniques in the Arabian Nights. Leiden: Brill.

Said, Edward. (1990). The Discourse of the Orient. In Dennis Walder (Ed.), Literature in the Modern World, (pp. 234-44). Oxford: Oxford University Press.

Said, Edward. (1979). Orientalism. London: Vintage.

Sanders, Julie. (2006). Adaptation and Appropriation. Oxon: Routledge.

Sironval, Margaret. (2006). The Image of Sheherazade in French and English Editions of The Thousand and One Nights (Eighteenth-nineteenth centuries). In Yuriko Yamanaka and Tetsuo Nishio (Eds.), The Arabian Nights and Orientalism: Perspectives From East \& West, (pp. 219-245). London: IB Tauris.

Stoker, Gilliarn Patricia. (1994). Sir John Tenniel: A study of his development as an artist, with particular reference to the Book Illustrations and Political Cartoons. Unpubl. Diss. King's College London.

Stovel, Nora Foster. (2007). Margaret Drabble. The Red Queen. The International Fiction review. 34.1 and 2.

Warner, Marina. (2011). Stranger Magic: Charmed States and the Arabian Nights. London: Chatto \& Windus.

Waugh, Patricia. (2002). Metafiction, the Theory and Practice of Self-Conscious Fiction. London \& New York: Routledge.

Wimsatt, W., \& Beardsley, M. (1946). The Intentional Fallacy. The Sewanee Review, 54(3), 468-488. Retrieved July 28, 2021, from http://www.jstor.org/stable/27537676

Yamanaka, Yuriko. (2006). The Arabian Nights and Orientalism. London: IB Tauris.

Yee, Jennifer. (2010). "A Review on Les Amoureux de Schéhérazade: variations modernes sur les 'Mille et une nuits'." French Studies. 64.1.

Zakeri, Bita Hazel. (2008). Echoes of Scheherazade's Voice in England: The Influence of the One Thousand and One Nights in the Works of Charlotte Bronte, Jane Austen, and Mary Hays. Southern Illinois University at Carbondale.

Bushra Juhi Jani is a lecturer in the College of Medicine/Al-Nahrain University. She received her $\mathrm{PhD}$ degree in English Literature from the University of Sheffield in 2018. She wrote her thesis on violence in Margaret Drabble's novels and four selected Iraqi novels. She published a number of research papers on Margaret Drabble and contemporary Iraqi novels. Her research interests lie in the area of English and Iraqi novels as well as Movie Studies. She is also interested in translating into English of Iraqi short stories and novels. She co-authored the translation of the first collection of short stories of the Iraqi novelist, Hadiya Hussein, which was self-published on Amazon. She also co-authored the translation of an anthology of Iraqi short stories, which comprised ten Iraqi storytellers. It was published by Lincom Academic Publisher in Germany 2019. 